\title{
ESTABLISHING A SELECTION FRAMEWORK FOR A LEAN AND VALUE ENGINEERING HYBRID METHODOLOGY
}

\author{
N.P. Gumede ${ }^{1 * \#} \&$ T.S. Hattingh ${ }^{2}$
}

\section{ARTICLE INFO}

\section{Article details}

Submitted by authors 15 Dec 2019 Accepted for publication 19 Aug 2020 Available online $\quad 14 \mathrm{Dec} 2020$

\section{Contact details}

* Corresponding author nosipho@wameconsulting.com

\section{Author affiliations}

1 Department of Mechanical, Industrial and Aeronautical Engineering, University of the Witwatersrand, South Africa

2 School of Industrial Engineering, North West University, South Africa

\# The author was enrolled for an MSc Eng (Industrial) degree in the Department of Mechanical, Industrial and Aeronautical Engineering, University of the Witwatersrand, South Africa

\section{ORCID® identifiers}

N.P. Gumede

https://orcid.org/0000-0001-6393-9224

T.S. Hattingh

https: / / orcid.org/0000-0001-5930-2546

DOI

http: / /dx.doi.org/10.7166/31-4-2299

\section{ABSTRACT}

The evolution of continuous improvement methodologies is evident in the formalisation of activities, their spread across disciplines, and the formation of hybrid methodologies. This study focuses on hybrid methodology formation, and specifically on lean and value engineering. It is proposed that hybrid methodologies be implemented using interchangeable use, concurrent use, and integrated use models; however, the literature does not provide distinct model definitions nor a formal framework to guide model selection. This study uses a systematic literature review to establish a model selection framework based on distinct model definitions. The aim of this framework is to support implementation and to create a standardised platform for future development, ultimately leading to improved and more sustainable success in implementation.

\section{OPSOMMING}

Die ontstaan van kontinue verbeteringsmetodologieë is duidelik in die formalisering van aktiwiteite, die verspreiding daarvan oor dissiplines en die samevoeging van hibriede metodologieë. Hierdie studie fokus op hibriede metodologie formasie, en spesifiek op lenige- en waardeingenieurswese. Die voorstel is dat hibriede metodologieë implementeer word deur middel van verwisselbare-gebruik modelle, konkurente-gebruik modelle en geïntegreerde-gebruik modelle. Die literatuur verskaf egter nie duidelike definisies vir ' $n$ formele raamwerk om model seleksie te lei nie. Hierdie studie gebruik 'n sistematiese literatuurstudie om 'n model-seleksie raamwerk te ontwikkel wat op duidelike model definisies geskoei is. Die doel van hierdie raamwerk is om die implementering te ondersteun en om 'n gestandardiseerde platform vir toekomstige ontwikkeling te skep. Dit sal uiteindelik lei tot verbeterde en meer volhoubare sukses in implementering.

\section{INTRODUCTION}

\subsection{Background and problem statement}

'Continuous improvement' is defined as the advancement of organisational performance through a planned, organised, and systematic approach [1]. The evolution of continuous improvement initiatives is evident in several ways, one of which is formalisation. The first evidence of continuous improvement initiatives dates back to the 1800s, when informal employee-driven improvements were encouraged and remunerated by management through reward schemes [2]. In the late 1800s these continuous improvement initiatives underwent a process of formalisation, when scientific methods were employed to solve production problems [3]. It was after World War II that the manufacturing industry pioneered two recognised continuous improvement methodologies Lean (the Toyota production system) and value engineering (VE) $[4,5]$. The Lean and VE methodologies that consist of terms and concepts that make them distinguishable. The progression from the informal, small-scale employee-driven methods of the 1800 s to today's distinguishable Lean and VE methodologies is evidence of the evolution of continuous improvement through formalisation. 
Further evidence of evolution is evident in the spread to other sectors. The application of Lean and VE methodologies originated in the manufacturing industry, but has not remained there. Both Lean and VE have been applied broadly in the South African context, including manufacturing, mining, healthcare, education, logistics, construction, retail, and banking $[6,7]$.

Last, and most relevant to this study, the evolution of continuous improvement is evident in the creation of hybrid methodologies, which are formed when individual continuous improvement methodologies are combined to realise benefits that are greater than those offered by one method [2,3]. Lean Six Sigma is a widely accepted hybrid methodology [2], while a less common hybrid methodology is a combination of Lean and VE. Although Lean Six Sigma is widely accepted, it is argued that the development of this hybrid methodology lacks a single approach that effectively combines Lean and Six Sigma [8]. Some authors [9] simply state that it is possible to use a single model to combine Lean and Six Sigma, but do not propose an approach. Others [10] acknowledge the continued existence of the uncertainty associated with the integration of Lean and Six Sigma, and suggest that the two methodologies are best combined through the assessment of critical success factors. Lean and VE hybrid methodologies follow similar development approaches [11-16], and typically involve the following steps (illustrated in Figure 1):

- $\quad$ The examination of Lean and VE theory and practices.

- A comparative analysis of Lean and VE to determine strengths and weaknesses or advantages and disadvantages. This analysis is based on organisational factors (products, processes, and system objectives).

- A comparative analysis of Lean and VE to determine similarities and differences or macrosimilarities/micro-differences (macro-similarities are broad similarities that are related to high-level strategic methodology principles; micro-differences are detailed differences that are related to tactics, techniques and procedures) [12, 15].

- $\quad$ The completion of a decision process.

- $\quad$ The implementation of a Lean and VE hybrid methodology using the selected model type.

Different terms have been used to describe Lean and VE hybrid methodology implementation models. Cell and Arratia [11] use terms such as 'concurrent' and 'integrated', while Nayak [12] employs terms such as 'connected', 'interdependent', and 'concurrent'. Some authors also claim that the existence of similarities can be used to justify the use of interchangeable models [12, 15]. Although authors use terms such as concurrent, integrated, connected, interdependent, and interchangeable use, distinct definitions for the terms are not provided. Also, some authors [17] use the term 'integrated' to describe all model types. To reduce the ambiguity, this study proposes three main models for the Lean and VE hybrid methodology:

- Interchangeable use models: the employment of either Lean or VE (or their components) in a substitutional way. Lean and VE are applied separately, and are mutually exclusive [12, 15].

- Concurrent use models: the simultaneous application of individual Lean and VE (or their components). Lean and VE are applied separately, and are mutually inclusive [11, 12].

- Integrated use models: the sequenced implementation of amalgamated Lean and VE (or their combined components). Lean and VE are connected and interdependent and form a coherent whole. Lean and VE are applied together through a merged structure [11, 12, 14, 16].

The literature on the Lean and VE hybrid methodology diverse implementation approaches, including concurrent and integrated use models $[11,12]$ and integrated use models only $[13,14,16]$, with some believing that Lean and VE similarities can be used to justify their interchangeable use [12, 15]. However, some frameworks in the literature emphasis the operational phases of implementation and the sequencing of Lean and VE activities, or only consider a single model type [11]. The framework presented by Nayak [10] depicts the convergence possibilities of Lean and VE based on focus, approach, techniques, and activities, but does not illustrate how the three implementation models relate to these convergence possibilities.

The decision-making process behind the selection of a particular approach is also not accompanied by a formalised framework to guide the model selection process. Practitioners are often instructed to establish the advantages and disadvantages of Lean and VE in the context of their own organisation's products, processes, and objectives [10], but are not provided with a guiding framework that can assist them with considering the three model types to determine the most suitable one for a particular application. A guiding decision-making framework is one of the critical success factors for Lean and VE implementation [7, 18]. It is this decision-making framework - the missing element - that this study aims to establish, as illustrated by the diamond shape in Figure 1. 


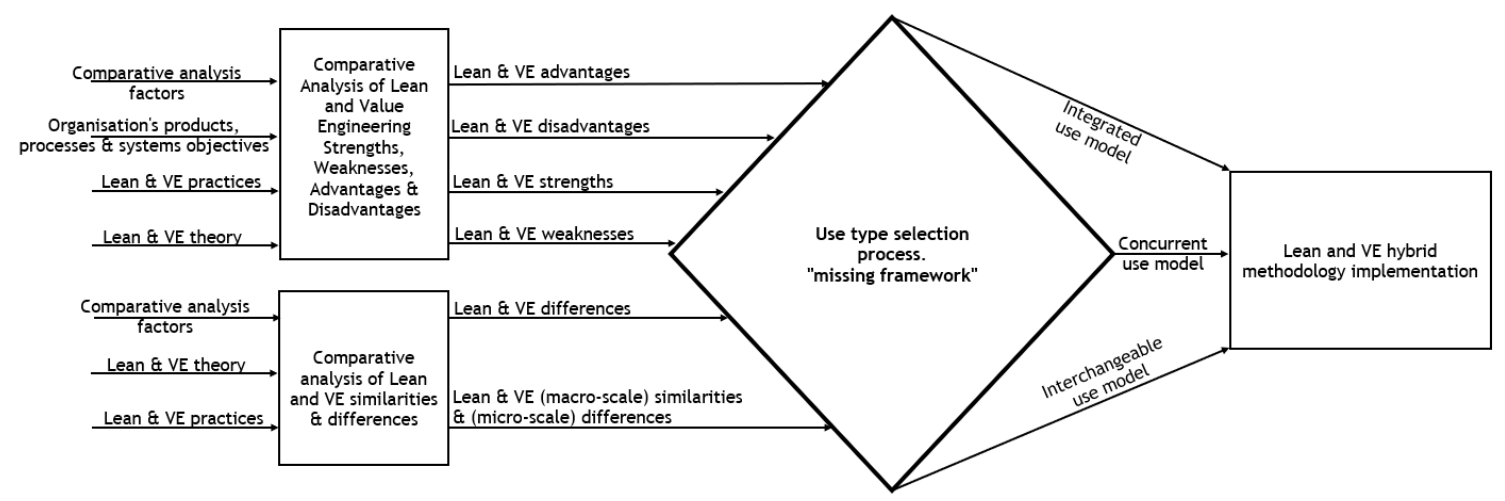

Figure 1: Lean and VE hybrid methodology development process

\subsection{Research objectives and questions}

It is acknowledged that the proposal of a Lean and VE hybrid methodology is based on a comparative analysis of the two methodologies; however, this study is not aimed at contrasting Lean and VE. There is an opportunity to benefit from implementing a Lean and VE hybrid methodology, and this study aims to develop a decision-making framework to guide the selection of interchangeable, concurrent, or integrated use models. It follows that the research question for this study is:

What framework can guide the selection of interchangeable, concurrent, or integrated use models in Lean and VE hybrid methodology?

The research question is addressed through the following objectives:

- $\quad$ Determine the variations of interchangeable, concurrent, and integrated use models that are present in the Lean and VE hybrid methodology literature

- $\quad$ Determine the principles that are associated with the interchangeable, concurrent, and integrated use models

- $\quad$ Establish a model selection framework based on these principles

\section{RESEARCH METHODOLOGY}

A systematic literature review methodology was selected, as it has the benefit of large-scale primary research to establish a framework that is more easily generalisable [19]. The systematic literature review was based on Fink's [20] definition, and follows a nine-phase approach [21], outlined in Table 1.

\section{Table 1: Systematic literature review methodology phases}

\begin{tabular}{|ll|l|}
\hline Phase & Description \\
\hline $\begin{array}{l}\text { 1. } \\
\text { Establish } \\
\text { queview }\end{array}$ & $\begin{array}{l}\text { The review question is the research question for this study: 'What framework can guide the } \\
\text { selection of interchangeable, concurrent, or integrated use models in a Lean and VE hybrid } \\
\text { methodology?' }\end{array}$ \\
\hline $\begin{array}{l}\text { Define } \\
\text { inclusion/ } \\
\text { exclusion } \\
\text { criteria }\end{array}$ & $\begin{array}{l}\text { Inclusion criteria: the document must be written in English: the content must include a } \\
\text { discussion of both Lean (or its respective synonyms) and VE (or its respective synonyms) } \\
\text { concepts; the content must include the proposal (or use, if it is an empirical study) of a Lean } \\
\text { and VE hybrid methodology; the proposal (or use) of a Lean and VE hybrid methodology must } \\
\text { be based on a documented model generation logic (see Figure 1) that indicates model } \\
\text { generation guiding principles (the principles may be implicit or explicit). }\end{array}$ \\
& $\begin{array}{l}\text { Exclusion criterion: documents that include a Lean (or its respective synonyms) and VE (or its } \\
\text { respective synonyms) hybrid methodology, but do not include a model generation logic } \\
\text { (Figure 1). }\end{array}$ \\
\hline 3. & $\begin{array}{l}\text { Form search } \\
\text { strategy }\end{array}$ & $\begin{array}{l}\text { The search strategy includes information data sources, type of literature reviewed (peer- } \\
\text { reviewed or grey literature), the searching method, search words, and the screening process. }\end{array}$ \\
\hline 4. & $\begin{array}{l}\text { Screen the } \\
\text { literature }\end{array}$ & $\begin{array}{l}\text { This phase aims to determine whether the retrieved literature meets the inclusion/exclusion } \\
\text { criteria. }\end{array}$ \\
\hline 5. & Report results & $\begin{array}{l}\text { The results are reported using the preferred reporting items for systematic reviews and } \\
\text { meta-analyses (PRISMA) flow diagram [22]. }\end{array}$ \\
\hline
\end{tabular}




\begin{tabular}{|ll|l|}
\hline Phase & Description \\
\hline 6. & $\begin{array}{l}\text { Critically } \\
\text { appraise }\end{array}$ & $\begin{array}{l}\text { The studies that are included are critically appraised, based on the comprehensiveness and } \\
\text { the quality of the evidence. }\end{array}$ \\
\hline 7. & Extract data & $\begin{array}{l}\text { The data is extracted according to a compiled checklist that is based on the Lean and VE } \\
\text { hybrid methodology development process outlined in Figure 1. }\end{array}$ \\
\hline 8. $\quad$ Synthesise & $\begin{array}{l}\text { The studies included are initially synthesised using narrative synthesis [23], followed by } \\
\text { framework, aggregative, and integrative synthesis [24] to facilitate the development of the } \\
\text { framework. }\end{array}$ \\
\hline 9. $\quad$ Conclude & $\begin{array}{l}\text { All information is consolidated to produce and record an outcome that satisfies the research } \\
\text { question. }\end{array}$ \\
\hline
\end{tabular}

\subsection{Data collection}

This study intends to identify models that represent the theoretical concepts of the Lean and VE hybrid methodology. The targeted outcome of this research is the generation of a framework for Lean and VE hybrid methodology model selection. Based on the intent and the targeted outcome, this research can be described as 'a theory-mining review' - specifically, a theory-landscaping [25] and knowledge-building and theory-generating review [26].

When literature is sought for theory-mining purposes, it must include peer-reviewed and grey literature to minimise publication bias and to locate newly proposed concepts that may be 'concealed' in grey literature sources [25]. Therefore, the review considered dissertations and theses, conference proceedings, in-house and non-commercial journal papers, reports, websites, scholarly journal papers, and practitioner publications.

Lean and VE both have alternative names, which necessitated a search for synonyms through an iterative process that was only halted when no new or relevant studies were retrieved [25]. The Lean search synonyms used were 'Toyota production system, 'continuous improvement', and 'Kaizen'. The VE search synonyms used were 'value methodology', 'value analysis', and 'value management'. The 'AND' Boolean operator [24] was used when searching for relevant Lean and VE relationships.

Lean and VE enjoy multidisciplinary application; so, it was important to select databases that contain multidisciplinary literature. The following databases and search engines were used: Scopus, Emerald Insight, Wiley Online, Taylor and Francis, ProQuest Central, Google Scholar, SAGE Journals Online, Web of Science, Google Search, Research Gate, WorldCat Dissertations and Theses, Digital Archive of Theses and Dissertations including Current and Completed Research, SAVE International Conference Proceedings, Institute of Value Management Australia Website, Hong Kong Institute of Value Management Website, Lean Enterprise Institute Africa Website, and Lean Global Institute Website.

A sample that includes both peer-reviewed and grey literature requires search methods that are suited to both types of literature. The most suitable methods are free-text searching, bibliographic searching, citation searching, and hand searching [24, 27]. All four methods were applied in this study.

\subsection{Reporting}

The search process was documented to ensure that the systematic review met transparency and reproducibility standards [24]. The retrieved literature was subjected to a screening process that involved the application of the inclusion/exclusion criteria to assess each paper based on its title, abstract, and full text. This process was documented using the standard PRISMA flow diagram [20]. The results of the screening process are illustrated in Figure 2. 


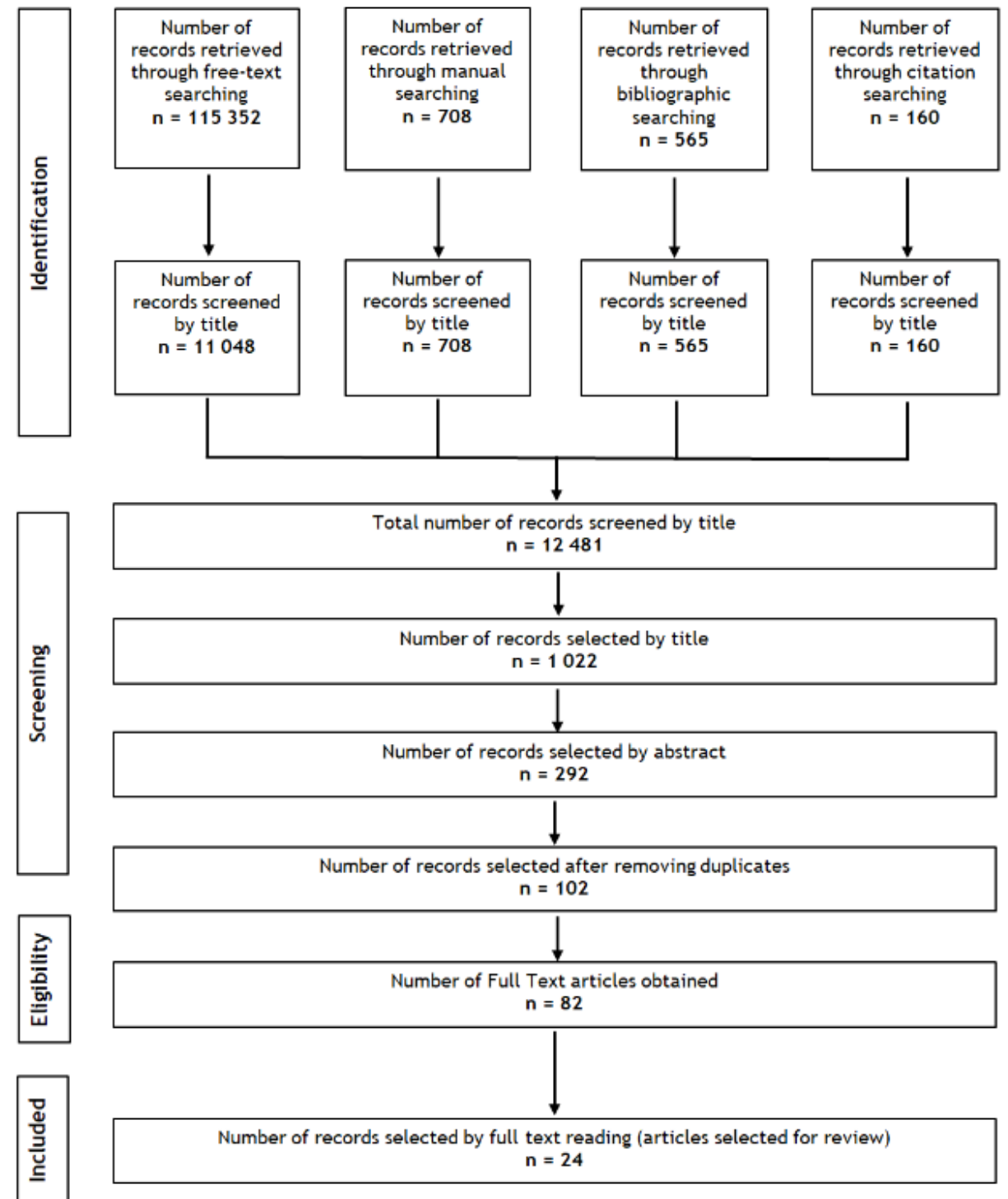

Figure 2: Search results PRISMA statement

\subsection{Data analysis and synthesis}

Research quality is a function of validity, reliability, and applicability [24]. A critical appraisal process was completed to assess the 24 selected review articles based on these three quality characteristics. Each article was assigned a score from 0 to 3 ('none' to 'high') for each factor, and these scores were then converted to percentage scores. No articles were excluded on the basis of quality, because it is not recommended for a theory-mining review [25]. The quality assessment was used to establish context and to indicate limitations and applicability.

After determining the quality of the included studies, the model development data was extracted based on the Lean and VE development process, illustrated in Figure 1. Nayak [12], Shekari and Fallahian [13], and Cell and Arratia [11] highlight the important characteristics of Lean and VE hybrid methodology models. These are selection, order, use, and purpose (SOUP, defined in Table 2). The SOUP analysis was used to determine the principles of the interchangeable, concurrent, and integrated use models. The results of this analysis were summarised in the form of findings. The findings were then examined and supplemented from the literature to develop a model selection framework. A narrative and framework synthesis [23, 24] was used to identify and analyse the findings, and an aggregative and integrative synthesis [24] was applied to develop the selection framework. 
Table 2: Hybrid model principles

\begin{tabular}{|l|l|}
\hline $\begin{array}{l}\text { Hybrid model } \\
\text { principles }\end{array}$ & Description \\
\hline Selection & $\begin{array}{l}\text { Describes the level of model selection: whether it is strategic (long-term, macro-scale, broad, } \\
\text { and related to organisation mission and plan) or tactical (short/medium-term, micro-scale, } \\
\text { detailed, and related to events, procedures, and projects). }\end{array}$ \\
\hline Order & $\begin{array}{l}\text { Details the time aspect of hybrid model implementation: whether the implementation of Lean } \\
\text { and VE elements is simultaneous, sequential, or substitutional. It also refers to the order of Lean } \\
\text { and VE components and the model structure. }\end{array}$ \\
\hline Use & $\begin{array}{l}\text { Details application area (project/product/service life cycle phase) or the condition in which the } \\
\text { model components are applied. It also describes the type of problems the components are } \\
\text { intended to solve. }\end{array}$ \\
\hline Purpose & $\begin{array}{l}\text { Describes the goal of hybrid model formation. The goal can include the following: } \\
\text { - Overcome individual methodology weakness } \\
\text { - Achieve synergistic benefits } \\
\text { Expand the scope of continuous improvement initiatives } \\
\text { Improve the effectiveness of continuous improvement initiatives }\end{array}$ \\
\hline
\end{tabular}

\section{RESULTS}

\subsection{Overview of articles}

Twenty-four peer-reviewed and grey literature papers were selected for review. These were published by practitioners and academics between 1991 and 2017. The authors of these articles all recommended the integration of Lean and VE; however, they did so for different purposes, based on the requirements of various sectors, disciplines, and sizes of enterprise. This section gives an overview of these articles, based on sector, author's profession, research approach, document type, publisher, and quality.

\subsubsection{Sector}

One form of Lean and VE evolution is the time-based spread from manufacturing to other sectors. The literature sample exhibits the outlined evolution attribute (Figure 3 ). The oldest review article was conducted in the manufacturing industry in 1991, and the most recent review article was conducted in the construction industry in 2017. Between 1991 and 2017, twenty-two articles described research that was deemed applicable in the product and service sectors, the public sector, the construction sector, and other sectors more broadly.

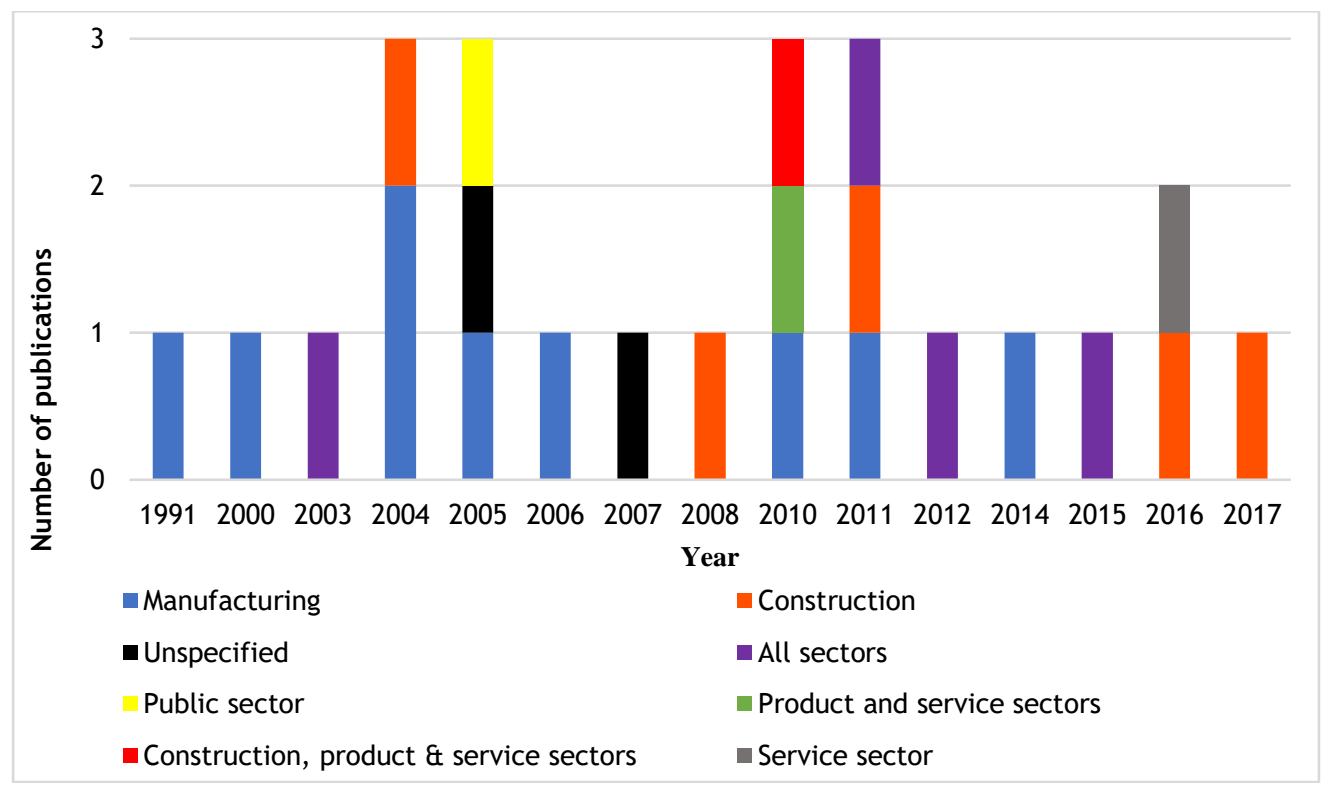

Figure 3: Sector-based number of publications per year (1991-2017)

Conversely, 75 percent of the review articles proposed the integration of components of Lean with components of VE to achieve context-specific objectives [13, 15, 17, 31-45]. Most (78\%) of these 18 articles 
were written by academics, with 61 percent being based on empirical research that included an analysis of the application of Lean and VE hybrid methodology models through case study research methodologies. Based on these differences, it was concluded that there are notable variations between the research conducted by academics and that by practitioners in the selected literature. However, it was evident that the differences are more a result of the research approach (theoretical versus empirical) than the author's profession (academic versus practitioner).

\subsubsection{Document type and publisher}

Four literature search methods were applied to obtain both peer-reviewed and grey literature from a variety of multidisciplinary sources; this was done to ensure that this review was as close as possible to exhaustiveness and expansiveness [26].

The data collection methods that were used resulted in a sample that included five document types: scholarly journal papers, dissertations and theses, conference papers by practitioners, conference papers by academics, and reports. The distribution of these documents is illustrated in Figure 5 . The selected review articles were obtained from 10 of the searched sources, although most of them were published by SAVE International and Research Gate.

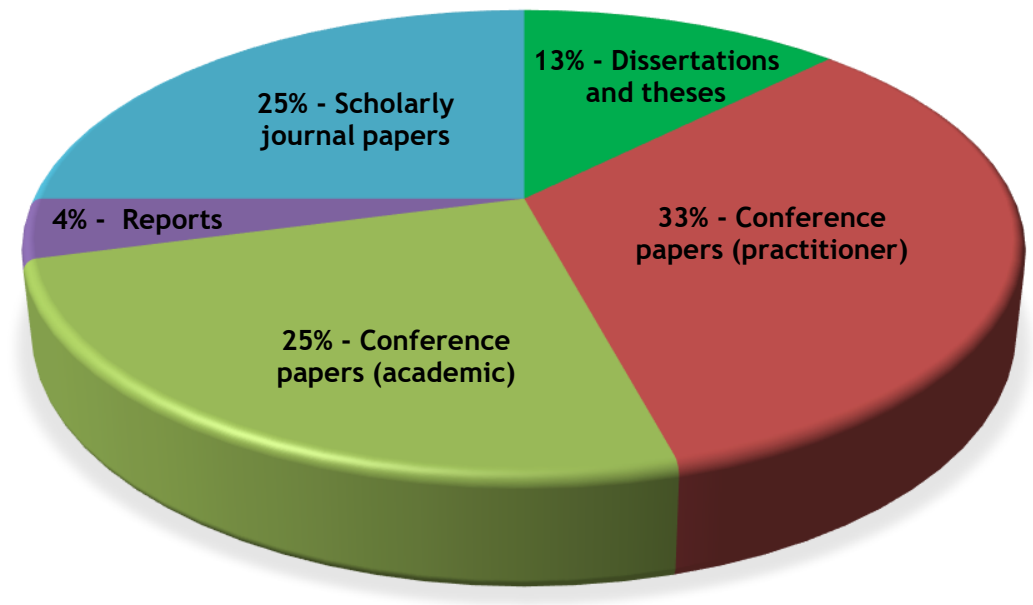

Figure 4: Distribution of articles by document type

\subsubsection{Quality}

The research quality was assessed using a critical appraisal process. The outcome of this process was a quality score based on applicability, validity, and reproducibility factors. The overall quality scores of most of the review articles were 50 percent and above; however, two scored less than 50 percent - primarily owing to unspecified data collection methods and a minimal review of the previous literature compared with the other articles. Nevertheless, all review articles scored above 50 percent for applicability. There was also agreement about Lean and VE hybrid methodology claims, proposals, and concepts among all the review studies that were included.

\subsection{Lean and VE hybrid methodology analysis}

This section contains an overview of the results obtained from the analysis of the Lean and VE hybrid methodology content. The specific elements analysed were the Lean and VE theory and practices that were used to form hybrid models, and the hybrid models that were recommended. The model principles are discussed in Section 4.

To complete this analysis, the 24 review articles were first separated, based on whether they included hybrid model proposals only (development research), or whether they included the empirical testing of the proposed hybrid models (application research). Most (63\%) of the review articles were classified as development research, while 37 percent were classified as application research. 


\subsubsection{Lean and VE theory and practices}

Lean and VE were designed separately without intending that their theoretical concepts, tools, and techniques be merged [12]. An analysis of the Lean and VE concepts, tools, and techniques that are commonly used to form hybrid models is thus included in this review.

The Lean and VE elements that are most commonly used to form hybrid models in both development and application research are shown in Table 3:

Table 3: Common Lean and VE hybrid model elements

\begin{tabular}{|c|c|c|}
\hline Methodology & Development research & Application research \\
\hline \multirow[t]{3}{*}{ Lean } & Value stream mapping & $\begin{array}{l}\text { Failure mode effect analysis (FMEA) and waste } \\
\text { analysis }\end{array}$ \\
\hline & Waste elimination & Lean thinking \\
\hline & Pull system & Value stream mapping and flow analysis \\
\hline \multirow[t]{3}{*}{ Value engineering } & Function analysis & Function analysis \\
\hline & The VE job plan & The VE job plan \\
\hline & & Function analysis system technique (FAST) \\
\hline
\end{tabular}

FMEA was included in this analysis because it is a component of total quality management, and total quality management is part of the Lean Lexicon [46]. The literature shows variations between development research and application research in the selection of Lean elements. However, this is not found in the selection of VE components. VE is an analytical technique, and thus the observed homogeneity is to be expected. Lean is a lexicon of cultural, management, and technical principles/tools/techniques, and thus the observed heterogeneity is to be expected.

\subsubsection{Identified hybrid models}

A total of 26 distinct Lean and VE hybrid methodology models emerged from the 24 articles that were examined. There are two more models than there are papers because some papers included more than one model. The summary of the models in Table 4 shows that 16 integrated use, two concurrent use, and zero interchangeable use models were identified in the development research articles, and that five integrated use, three interchangeable use, and no concurrent use models were identified in the application research articles.

Table 4: Identified hybrid models

\begin{tabular}{|c|c|c|c|}
\hline Model description & $\begin{array}{c}\text { Development } \\
\text { research: Number of } \\
\text { models }\end{array}$ & $\begin{array}{c}\text { Application research: } \\
\text { Number of models }\end{array}$ & $\begin{array}{c}\text { Total number of } \\
\text { models }\end{array}$ \\
\hline Integrated use & 16 & 5 & 21 \\
\hline Interchangeable use & 0 & 3 & 3 \\
\hline Concurrent use & 2 & 0 & 2 \\
\hline Total & $\mathbf{1 8}$ & $\mathbf{8}$ & $\mathbf{2 6}$ \\
\hline
\end{tabular}

\section{ANALYSIS AND DISCUSSION}

\subsection{Synthesis of findings using the hybrid model principles}

The models listed in Table 4 have principles that relate to the level of model selection, how the models are ordered, the applications in which the models are used, and the purpose of the models. The model characteristics were analysed using the SOUP procedure, which revealed thirty distinct findings that are presented in Tables 5-8.

\subsubsection{The selection principle}

The findings in Table 5 suggest that interchangeable use models are endorsed for tactical initiatives and combined strategic/tactical initiatives, and that integrated use models are chosen for tactical, strategic, and combined strategic/tactical level initiatives. However, it was found that concurrent use models are typically only recommended for tactical level initiatives. The observed differences between integrated use models and the other two models can be attributed to the fact that a large number (21) of integrated use models were analysed, resulting in more comprehensive findings. The differences may also be attributed to the fact that Lean is regarded as an operational philosophy that can influence organisational strategy, while VE is described as an analytical tool that is often used for tactical activities [11, 12,15]. This study uses 'VE' as a synonym for value methodology. While VE may be described as an analytical tool, the value methodology involves three types of technique: value management (suitable for strategic initiatives), value 
engineering (suitable for tactical initiatives), and value analysis (suitable for technical initiatives) [7]. The scope of value methodology thus allows for the application of interchangeable use and concurrent use model implementation for strategic level initiatives.

\section{Table 5: SOUP analysis findings (selection)}

\begin{tabular}{|l|l|}
\hline Model type & Finding description \\
\hline Interchangeable use & $\begin{array}{l}\text { Selected for a combination of strategic and tactical level initiatives [32] } \\
\text { Selected for tactical level initiatives [31, 37] }\end{array}$ \\
\hline Concurrent use & Selected for tactical level initiatives [17] \\
\hline Integrated use & Selected for tactical level initiatives [11, 12, 14, 17, 30, 34, 35, 38, \\
& $40,41,44,45]$ \\
& Selected for strategic level initiatives [11, 30] \\
& Selected for a combination of strategic and tactical level initiatives [13, \\
& $16,29]$ \\
\hline
\end{tabular}

\subsubsection{The order principle}

The definitions of the three model types indicate that Lean and VE may be applied using the following arrangements: substitutional implementation (interchangeable use models), simultaneous implementation (concurrent use models), and sequenced implementation (integrated use models). The findings in Table 6 reveal additional characteristics of the Lean and VE hybrid model arrangements.

Table 6: SOUP analysis findings (order)

\begin{tabular}{|c|c|}
\hline Model type & Finding description \\
\hline Interchangeable use & $\begin{array}{l}\text { Lean and VE applied in a substitutional manner based on macro-level } \\
\text { similarities and micro-level differences [31, 32,37]. } \\
\text { VE implementation before Lean, because VE is more suitable for early- } \\
\text { stage product/process design activities [32]. } \\
\text { Lean implementation before VE if the Lean initiative takes place on the } \\
\text { shop floor (where all implementation activities occur) [37]. }\end{array}$ \\
\hline Concurrent use & $\begin{array}{l}\text { Simultaneous Lean and VE implementation when hybrid initiative requires } \\
\text { agreement between Lean and VE output to avoid waste [17]. }\end{array}$ \\
\hline Integrated use & $\begin{array}{l}\text { VE implementation before Lean implementation to ensure subsequent } \\
\text { steps are directed by customer function requirements }[17,45] \text {. } \\
\text { Lean implementation before VE to create opportunities for subsequent VE } \\
\text { implementation [11, 12]. } \\
\text { The addition of VE components to a sequenced and unaltered Lean } \\
\text { practice, or vice versa [11, } 12,16,29,30,35,38,44] \text {. } \\
\text { Lean implementation before VE to ensure that the first step involves value } \\
\text { definition [13]. } \\
\text { Lean implementation before VE to create an environment or culture in } \\
\text { which VE can be applied easily or successfully [13]. } \\
\text { The addition of VE components to a sequenced and unaltered Lean Six } \\
\text { Sigma practice [14]. } \\
\text { An amalgamation of Lean and VE at every step in the sequence [16, 40]. }\end{array}$ \\
\hline
\end{tabular}

The findings suggest that the arrangement of hybrid models may be selected only when certain requirements are satisfied. For instance, substitutional use is applied when a combination of macro-level similarities and micro-level differences is identified. This is to be expected, because Nayak [12] and Musa, Pasquire and Hurst [15] propose that substitutional use is only possible when similarities exist. The findings also imply that the arrangement of hybrid models may be selected to satisfy certain requirements; and they demonstrate that the hybrid model arrangement characteristics may also be related to whether Lean is implemented before VE or vice versa. This factor is irrelevant for concurrent use models, but is most significant for integrated use models, because these rely on the interdependence of Lean and VE. The findings show that, in interchangeable use model application, Lean or VE can be implemented first, based on the product/process life cycle stage and the area in which the initiative occurs. For integrated use application, this may be influenced by the focus of the initiative, the existence of implementation opportunities, and the organisational culture. Another factor that influences the order is the model structure. This factor is particularly significant for integrated use models because they involve an amalgamation of Lean and VE components. The findings show that integrated use models can involve the addition of Lean components to an unaltered VE structure (or vice versa), or the amalgamation of Lean and VE at every step in the sequence, which results in a new structure. 


\subsubsection{The use principle}

One of the most commonly discussed Lean and VE differences is related to where (area) and when (time/stage) the methodologies can be applied. The findings in Table 7 suggest that interchangeable use models may involve the substitutional application of Lean and VE in dissimilar application areas, or in the same application areas but in dissimilar application conditions, or the substitutional application of Lean and VE at different stages of a product/process life cycle. Similarly, the findings imply that integrated use models may include the sequential application of Lean and VE in the same application area, or in dissimilar application areas, or in different size organisations. The findings indicate that concurrent use models may comprise the application of Lean and VE in similar application areas only; however, the literature [11, 12] suggests that concurrent use models can also involve the application of Lean and VE in dissimilar application areas.

Table 7: SOUP analysis findings (use)

\begin{tabular}{|l|l|}
\hline Model type & Finding description \\
\hline $\begin{array}{l}\text { Interchangeable } \\
\text { use }\end{array}$ & $\begin{array}{l}\text { Lean and VE applied in a substitutional manner in dissimilar product/ process life cycle stages } \\
\text { (VE-design/ Lean-production) [32] } \\
\text { Substitutional implementation of Lean and VE in dissimilar application areas [32, 37] } \\
\text { Substitutional implementation of Lean and VE in the same application area but in dissimilar } \\
\text { application conditions [31] }\end{array}$ \\
\hline Concurrent use & Simultaneous Lean and VE implementation in the same application area [17] \\
\hline Integrated use & $\begin{array}{l}\text { Sequential Lean and VE implementation in the same application area [11, 17, 35, 40, 41, } \\
\text { 44] } \\
\text { Sequential Lean and VE implementation in dissimilar application areas [13] } \\
\text { The use of sequential amalgamation of Lean and VE components, based on their suitability to } \\
\text { organisational size [38] }\end{array}$ \\
\hline
\end{tabular}

\subsubsection{The purpose principle}

Hybrid methodologies are formed for a specific purpose. Often the purpose can be achieved through the implementation of any of the three hybrid model types - for example, expanding scope, overcoming weaknesses, improving effectiveness, developing competitive advantage, or achieving a waste/value balance. However, sometimes the purpose is unique to a specific model type. For instance, synergistic benefits can only be achieved through the implementation of integrated use models, while interchangeable use models are the only ones that can be purposed to achieve the same Lean and VE macro objectives in dissimilar areas and conditions (Table 8). However, the use characteristics (Table 7) of the other two models indicate that they too can be purposed to achieve similar macro-objectives in dissimilar application areas. The main difference lies in how the macro-objectives are achieved - whether they are achieved through mutually exclusive substitutional Lean and VE implementation (interchangeable use), mutually inclusive Lean and VE implementation (concurrent use), or sequential Lean and VE implementation (integrated use). The findings also reveal that integrated use models may involve the simultaneous and substitutional use of Lean and VE components within a sequence.

Table 8: SOUP analysis findings (purpose)

\begin{tabular}{|l|l|}
\hline Model type & Finding description \\
\hline $\begin{array}{l}\text { Interchangeable } \\
\text { use }\end{array}$ & $\begin{array}{l}\text { Achieve the same Lean and VE objectives (eliminate NVA, minimise cost, evaluate operation) } \\
\text { in dissimilar application areas [37] } \\
\text { Achieve the same Lean and VE objective (value increase) in the same application area but in } \\
\text { different application conditions [31] }\end{array}$ \\
\hline Concurrent use & Improve the effectiveness of individual Lean and VE methodologies [17] \\
\hline Integrated use & $\begin{array}{l}\text { Improve the effectiveness of individual Lean and VE methodologies [17, 29] } \\
\text { Overcome the weakness of individual Lean and VE methodologies [11, 41] } \\
\text { Expand the scope of individual Lean and VE methodologies [11, 30, 38] } \\
\text { Realise synergistic benefits [12-16] }\end{array}$ \\
\hline
\end{tabular}

\subsection{Hybrid model selection framework}

It is evident that the three model types share certain characteristics; however, some traits are unique to each model type. The model characteristics that were discovered in the SOUP analysis were supplemented from the literature, and this combination was used to develop the proposed model selection framework (Figures 5 and 6). This framework is a graphical representation of the findings summarised in Tables 5-8.

The practitioner can use the proposed framework in the following way: 
- For each principle (selection, order, use, and purpose), analyse the organisational context using the guidelines in the framework to determine whether the context conditions meet interchangeable use, concurrent use, or integrated use criteria. The selection and order conditions and the correlating criteria are shown in Framework Part I (Figure 5), and the utilisation and purpose conditions and the correlating criteria are shown in Framework Part II (Figure 6).

- Once the criteria for each principle have been established, the best-suited model can be chosen - e.g., if interchangeable use criteria have been met for all four principles, then select an interchangeable use model; if concurrent use criteria have been met for all four principles, then select a concurrent use model; or if integrated use criteria have been met for all four principles, then select an integrated use model. These relationships are provided at the end of Framework Part II.

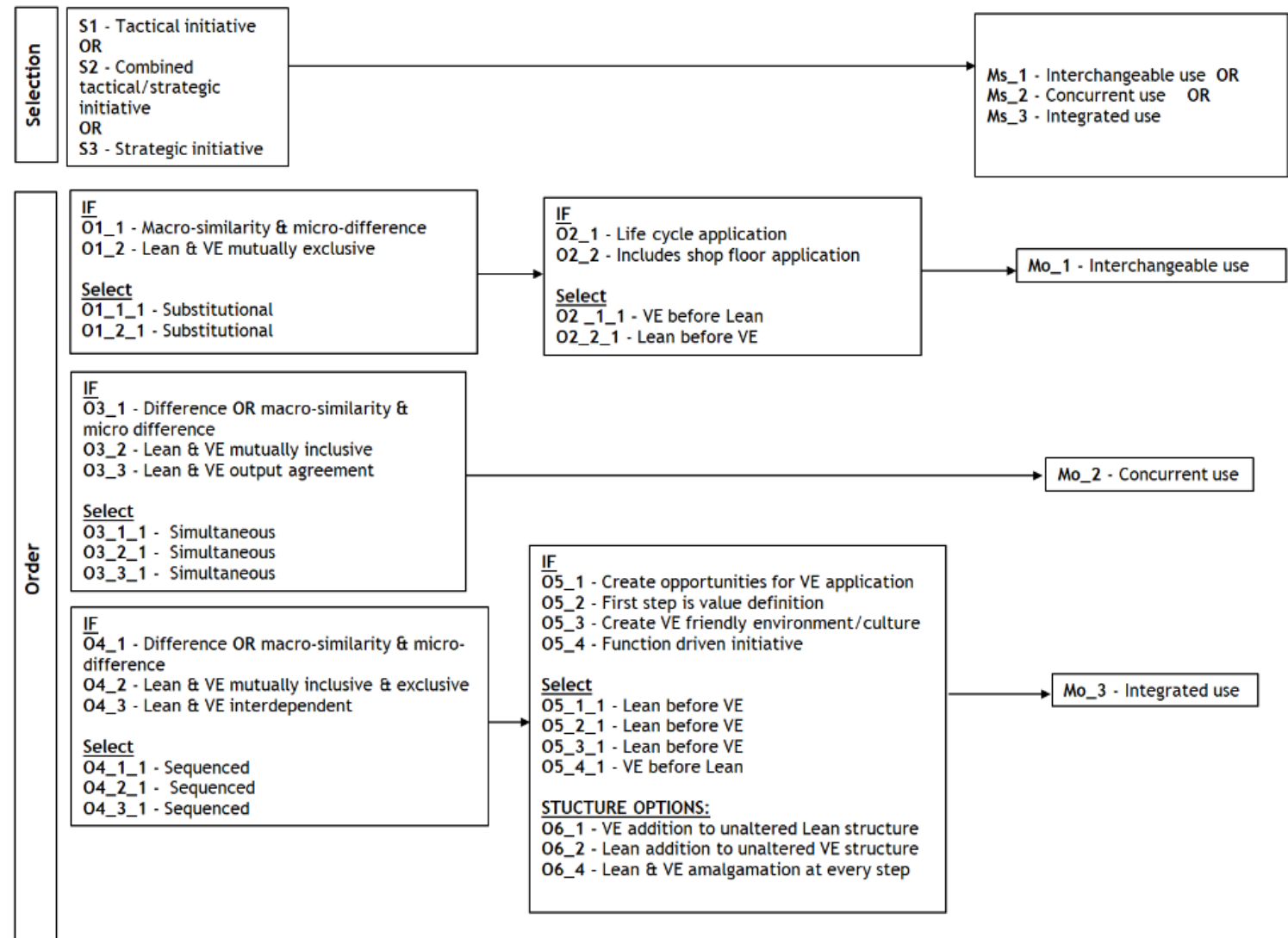

Figure 5: Lean and VE hybrid methodology selection framework Part I 


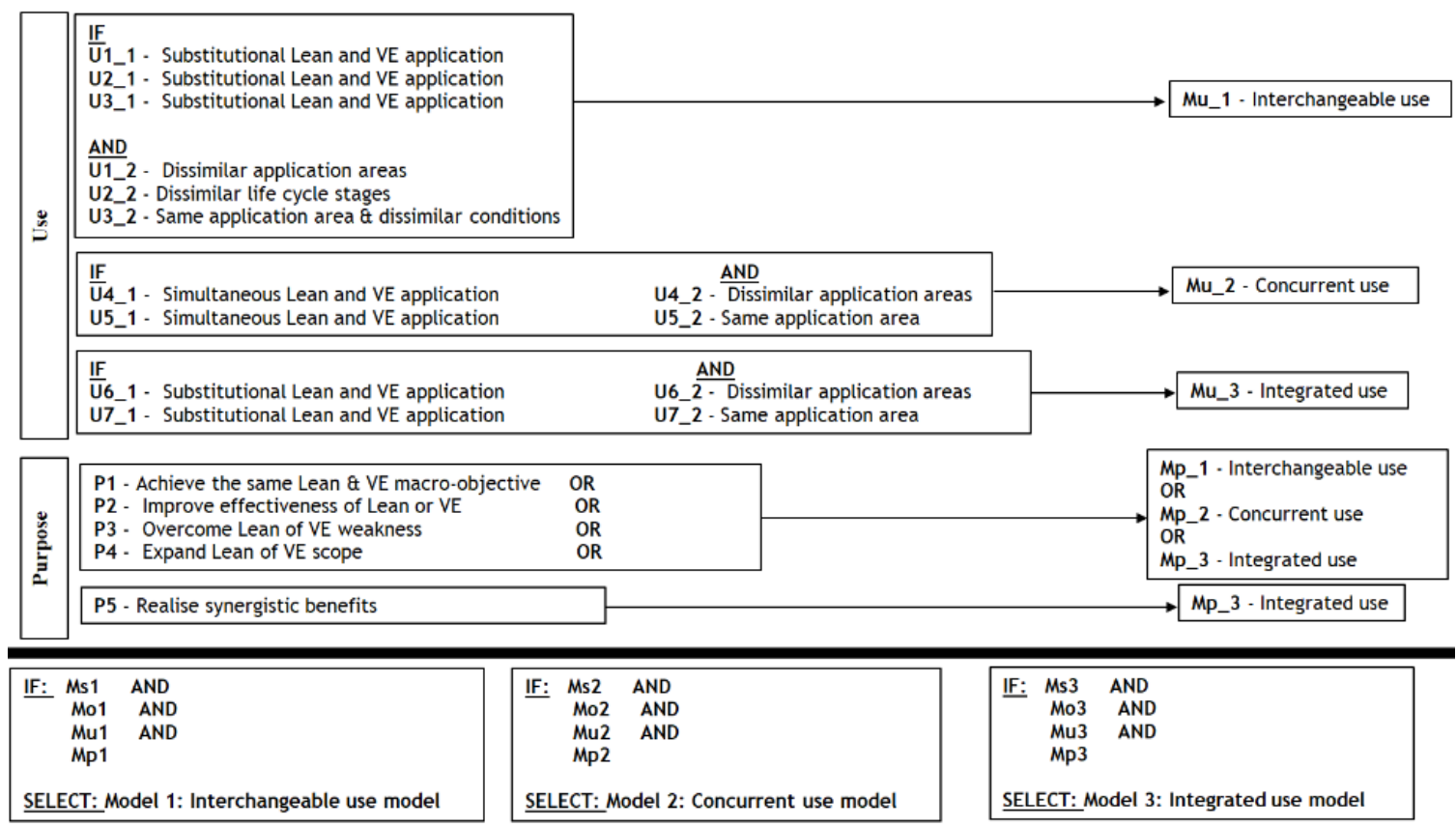

Figure 6: Lean and VE hybrid model selection framework Part II

\section{CONCLUSIONS}

This study proposes that a Lean and VE hybrid methodology can be applied using three types of models: interchangeable use, concurrent use, and integrated use.

The Lean and VE hybrid model was shown to have characteristics that are related to selection, order, use, and purpose. These characteristics can be employed to guide the hybrid methodology selection. A model selection framework was thus established using these characteristics.

This research is valuable to researchers, scholars, and practitioners. It reports on the current state of the body of knowledge on Lean and VE hybrid methodology and proposes a hybrid selection model that is intended to guide implementation and facilitate empirical research. It also adds structure to Lean and VE hybrid methodology implementation by proposing a systematic approach to hybrid model implementation.

\section{RECOMMENDATIONS}

The proposed framework is based on thirty findings that were discovered in twenty-four research sample articles; the selected articles were based on the SLRM search strategy and the inclusion/ exclusion criteria of this study. The framework is thus limited by the number of findings, the search strategy, and the inclusion/ exclusion criteria. It is recommended that further study be conducted to improve its expansiveness and exhaustiveness.

The findings that were used to develop the framework were obtained from a theoretical research perspective grounded mainly in the manufacturing industry. It is recommended that the proposed framework be refined by considering only hybrid models that have been tested empirically, and by exploring the literature further to find samples from a wider range of contexts.

Lean and VE were not designed to be combined, and so it is recommended that the key success factors for Lean and VE hybrid methodology implementation be investigated to overcome this challenge. There is also an opportunity to explore how the differences in Lean and VE jargon, entry costs, resource use, application strategy training requirements, and team composition can be leveraged beneficially. 
The limitations of the framework present an opportunity for both industry and researchers to conduct theoretical and empirical research to minimise those limitations. Despite them, the findings of the research offer notable implications for the Lean and VE body of knowledge and for industry.

This research adds to the Lean and VE body of knowledge by being a central access point for consolidated Lean and VE hybrid methodology data. The reviewed literature did not provide distinct definitions for Lean and VE hybrid models. Some authors used 'integrated model' as a blanket term for all Lean and VE hybrid models. This study adds to the Lean and VE body of knowledge by offering three model categories (interchangeable use, integrated use, and concurrent use) that have distinct definitions. The main output of this study is a Lean and VE hybrid model selection framework that serves as a practical guide for the Lean and VE hybrid methodology practitioner. It enables the practitioner to analyse their context based on four model principles, to determine the appropriate use type, and to select the most suitable Lean and VE model. The framework is a coded and structured guide that can be digitised and implemented by nonexperts.

\section{REFERENCES}

[1] Gonzalez Aleu, F. \& Van Aken, E.M. 2016. Systematic literature review of critical success factors for continuous improvement projects. International Journal of Lean Six Sigma, 7, pp. 214-232.

[2] Bhuiyan, N. \& Baghel, A. 2005. An overview of continuous improvement: From the past to the present. Management Decision, 43, pp. 761-771.

[3] Singh, J. \& Singh, H. 2015. Continuous improvement philosophy - Literature review and directions. Benchmarking: An International Journal, 22, pp. 75-119.

[4] Lane Davis, K. 2004. Finding value in the value engineering process. Cost Engineering, 46, pp. 24-27.

[5] Lean Enterprise Institute. 2000. A brief history of Lean. Available at: https://www. lean.org/WhatsLean/History.cfm (Accessed 21 February 2019).

[6] Dondofema, R.A., Matope, S. \& Akdogan, G. 2017. Lean applications: A survey of publications with respect to South African industry. South African Journal of Industrial Engineering, 28, pp. 103-113.

[7] VM Services. 2017. Value engineering and value analysis handbook. Johannesburg: VM Services.

[8] Pepper, M.P.J. \& Spedding, T.A. 2010. The evolution of lean Six Sigma. International Journal of Quality \& Reliability Management, 27, pp. 138-155.

[9] Pacheco, D., Pergher, I., Vaccaro, G.L.R. \& Jung, C.F. 2015. 18 comparative aspects between Lean and Six Sigma: Complementarity and implications. International Journal of Lean Six Sigma, 6, pp. 161-175.

[10] Alhuraish, I., Robledo, C. \& Kobi, A. 2017. A comparative exploration of lean manufacturing and six sigma in terms of their critical success factors. Journal of Cleaner Production, 164, pp. 325-337.

[11] Cell, C.L. \& Arratia, B. 2003. Creating value with lean thinking and value engineering. In: 43rd Annual Society of American Value Engineers International Annual Conference, Scottsdale, Arizona, USA, 7-11 June 2003.

[12] Nayak, B. 2006. Lean manufacturing and value management convergence of divergent tools. In: 46th Annual Society of American Engineers: Managing projects to maximize value, Savannah, Georgia, USA, 4-7 June 2006, pp. 342-359.

[13] Shekari, A. \& Fallahian, S. 2007. A new approach to linking value engineering and lean methodology. In: 19th International Conference on Production Research, Valparaiso, Chile, 29 July - 2 August 2007.

[14] Mandelbaum, D.J., Williams, H. \& Hermes, A. 2010. Value engineering synergies with Lean Six Sigma. IDA Paper P-4586, Virginia: Institute for Defense Analyses.

[15] Musa, M.M., Pasquire, C. \& Hurst, A. 2016. Where lean construction and value management meet. In: 24th Annual Conference of the International Group for Lean Construction, Boston, Massachusetts, USA, 18-24 July 2016, pp. 103-112.

[16] Ekanayake, E.M.A.C. \& Sandanayake, Y.G. 2017. LiVE approach: Lean integrated value engineering for construction industry. Built Environment Project and Asset Management, 7, pp. 518-533.

[17] Ho, D.C.K., Cheng, E.W.L. \& Fong, P.S.W. 2000. Integration of value analysis and total quality management: The way ahead in the next millennium. Total Quality Management and Business Excellence, 11, pp. 179-186.

[18] Haque, S. \& Chaudhuri, S.R. 2015. Framework of training for Lean service. Drishtikon: A Management Journal, 7. Epub ahead of print. DOI: 10.21863/drishtikon/2015.7.1.011.

[19] Boland, A., Cherry, M.G. \& Dickson, R. (eds). 2017. Doing a systematic review: A student's guide. 2nd edition. Thousand Oaks, CA: SAGE Publications.

[20] Fink, A. 2005. Conducting research literature reviews: From the internet to paper. Thousand Oaks, CA: SAGE.

[21] Gough, D. 2007. Weight of evidence: A framework for the appraisal of the quality and relevance of evidence. Research Papers in Education, 22, pp. 213-228.

[22] PRISMA. 2015. PRISMA-statement. Available at: http://www.prisma-statement.org/ (Accessed 15 March 2019).

[23] Popay, J., Roberts, H., Sowden, A., Petticrew, M., Arai, L., Rodgers, M., Britten, N., Roen, K., Duffy, S. 2006. Guidance on the conduct of narrative synthesis in systematic reviews: A product from the ESRC Methods Programme. Lancaster University. Epub ahead of print. DOI: 10.13140/2.1.1018.4643.

[24] Booth A., Sutton, A. \& Papaioannou, D. 2016. Systematic approaches to a successful literature review. 2nd ed. Los Angeles: Sage. 
[25] Okoli, C. 2015. The view from giants' shoulders: Developing theory with theory-mining systematic literature reviews. Available at:

https://www.academia.edu/19557981/The_View_from_Giants_Shoulders_Developing_Theory_with_TheoryMining_Systematic_Literature_Reviews (Accessed 7 March 2019).

[26] Finfgeld-Connett, D. \& Johnson, E.D. 2013. Literature search strategies for conducting knowledge-building and theory-generating qualitative systematic reviews: Literature search strategies. Journal of Advanced Nursing, 69, pp. 194-204.

[27] Mahood, Q., Van Eerd, D. \& Irvin, E. 2014. Searching for grey literature for systematic reviews: Challenges and benefits. Research Synthesis Methods, 5, pp. 221-234.

[28] Bartunek, J.M. \& Rynes, S.L. 2014. Academics and practitioners are alike and unlike: The paradoxes of academicpractitioner relationships. Journal of Management, 40, pp. 1181-1201.

[29] Parker, D.E. 2015. Lean as a value enhancing methodology. In: Society of American Value Engineers Value Summit 2015. San Diego, CA, USA, pp. 87-94.

[30] Watson, G.H. 2005. Putting value back into engineering. In: ASQ World Conference on Quality and Improvement Proceedings. American Society for Quality, Seattle, Washington, USA, 16-18 May 2005, pp. 163-174.

[31] Borgianni, Y., Cascini, G. \& Rotini, F. 2010. Wood pellet manufacturing improvements through product-driven process value analysis. Journal of Engineering Manufacture, Proceedings of the Institution of Mechnical Engineers, 225, pp. 761-772.

[32] Chakravartty, U. 1991. Value analysis and value engineering as a cost reduction tool and its relation with JIT manufacturing, Masters thesis, University of Texas, El Paso. AAIEP04136. Available at: https://scholarworks.utep.edu/dissertations/AAIEP04136 (Accessed 12 June 2019).

[33] De Hemmer, 0. 2012. Value(s) and management: There's value everywhere! In: Proceedings of the International Conference on Value Engineering and Management: Innovation in the Value Methodology, ICVEM 2012, Hong Kong, 6-7 December 2012, pp. 111-116.

[34] Kheradia, A. 2011. TALEVAS model: An integrated quality methodology. The TQM Journal, 23, pp. 403-422.

[35] Lee, L.J.-H., Leu, J.-D. \& Huang, Y.-W. 2016. Using ICT to improve service quality. International Journal of Electronic Business Management, 14, pp. 53-61.

[36] Lehman, T. \& Reiser, P. 2004. Maximizing value \& minimizing waste: Value engineering \& lean construction. In: Society of American Value Engineers International 44th Annual Conference Proceedings, Montreal, Canada, July 2004.

[37] Nassey, E.Z. 2004. Implementation of lean method and value analysis in the sandblasting production shop at Intersign Corporation, Masters thesis, University of Tennessee at Chattanooga, Chattanooga. Available at: https://scholar.utc.edu/theses/606/ (Accessed 26 June 2019)

[38] Odedairo, B.O. \& Bell, D. 2010. Framework for introducing and implementing value methods: A novel toolkit for small and medium scale industries in developing nations. International Journal of Basic \& Applied Sciences (IJBAS), 9, pp. 130-146.

[39] Ogunbiyi, O., Oladapo, A. \& Goulding, J. 2011. Innovative value management: Assessment of lean construction implementation. In: COBRA 2011 Proceedings of RICS Construction and Property Conference, University of Salford, Manchester, England, 12-13 September 2011, pp. 696-709.

[40] Prahladaraj, S. 2004. Integration of lean manufacturing and value engineering techniques to improve the internal distribution system in a manufacturing company, University of Tennessee at Chattanooga, Chattanooga. Available at:

https: //scholar.utc.edu/theses/607/ (Accessed 26 June 2019)

[41] Sacadura, L.M.F.C. \& Tenera, A.M.B.R. 2011. Integrating value and lean management in manufacturing processes. In: 2011 International Conference on Management and Service Science, IEEE, Wuhan, China, 12-14 August, pp. 15.

[42] Salvatierra-Garrido, J. 2011. Conceptualising value for construction: Experience from social housing projects in Chile. Loughborough University. Available At: https://dspace.lboro.ac.uk/2134/9418 (Accessed 22 June 2019)

[43] Thorsen, W.C. 2005. Value stream mapping \& VM. In: 45th Annual Conference of Society of American Value Engineers International. San Diego, California, USA, 26-29 June 2005, pp. 288-295.

[44] Wixson, J.R. 2005. A value management approach to improving quality performance. In: 45th Annual Conference of Society of Value Engineers International. San Diego, CA, USA, pp. 129-146.

[45] Wohnhas, S. 2014. Value management in lean product development. In: Society of American Value Engineers Value Summit 2014. Oakbrook, Illinois, USA, 22-26 June 2014, pp. 184-190.

[46] Lean Enterprise Institute. Total quality management in the Lean Lexicon ${ }^{\odot}$. Available at: https://www.lean.org/lexicon/total-quality-management (Accessed 28 August 2019). 